Международная Научно-Исследовательская Федерация «Общественная наука»

\title{
Научные тенденции: Архитектура, География, Геология
}

Сборник научных трудов

по материалам

IV международной научной конференции

28 октября 2017 г.

\section{LJOURNAL.RU}

Санкт-Петербург 2017 
УДК 001.1

ББК 60

Научные тенденции: Архитектура, География, Геология. Сборник научных трудов, по материалам IV международной научно-практической конференции 28 октября 2017 г. Изд. ЦНК МНИФ «Общественная наука», 2017. - 16с.

\section{SPLN 001-000001-0197-AG \\ DOI 10.18411/spc-28-10-2017 \\ IDSP 000001:spc-28-10-2017}

В сборнике научных трудов собраны материалы из различных областей научных знаний. В данном издании приведены все материалы, которые были присланы на IV международную научно-практическую конференцию Научные тенденции: Архитектура, География, Геология.

Сборник предназначен для научных работников, преподавателей, аспирантов и студентов.

Все материалы, размещенные в сборнике, опубликованы в авторском варианте. Редакция не вносила коррективы в научные статьи. Ответственность за информацию, размещенную в материалах на всеобщее обозрение, несут их авторы.

Информация об опубликованных статьях будет передана в систему Российского индекса научного цитирования (РИНЦ) и наукометрическую базу SPINDEX

Электронная версия сборника доступна на сайте ЦНК МНИФ «Общественная наука». Сайт центра: conf.sciencepublicru

УДК 001.1

ББК 60 


\section{Содержание}

Козырева Е.А. Ближние усадьбы высшей знати, как феномен историкоградостроительной жизни Санкт-Петербурга, на примере усадьбы

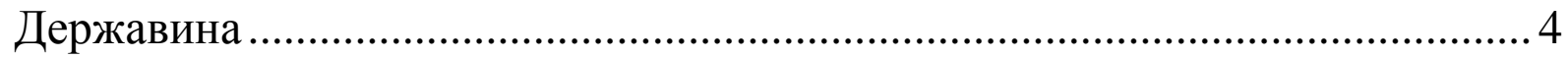

Матвеев М.Г., Сбеглов В.А. Альтернативы пространственной организации городов ............................................................................... 7

Найденова И.В. Преемственность процессов модернизации аграрного сектора г. Корочи в рамках концепции развития агропромышленного комплекса Белгородской области

Пешкова Д.А. Выявление проблем типологического разнообразия городского жилья для людей пенсионного возраста 13 


\section{Козырева Е.А. \\ Ближние усадьбы высшей знати, как феномен историко-градостроительной жизни Санкт-Петербурга, на примере усадьбы Державина}

Санкт-Петербургский государственный архитектурно-строительный университет

doi: $10.18411 / s p c-28-10-2017-01$

(Россия, Санкт-Петербург)

idsp: 000001:spc-28-10-2017-01

\section{Аннотация}

В работе рассматривается феномен ближних усадеб высшей знати, как часть истории и градоформирующий аспект в формировании города Санкт-Петербурга и его окрестностей. Более подробно рассматривается история и этапы формирования, строительства и реконструкции усадьбы Державина, как одного из примеров ближних усадеб высшей знати. Данный объект был создан талантом выдающихся зодчих, но уже в ХІХвеке начались работы по приспособлению его территории и здания для развивающейся территории города. Проблемы сохранения и приспособления для современного использования в настоящее время такого типа объектов остро стоят перед архитектурным сообществом.

Ключевые слова: усадьбы высшей знати, усадьба Державина, проблемы сохранения объекта.

В Санкт-Петербурге и вокруг Санкт-Петербурга до 1917Г можно отметить наличие усадеб, которые по своему содержанию и амбициозности, могут в чем-то поспорить с Императорскими загородными дворцово-парковыми комплексами. Но в тоже время имеют характерные отличительные особенности, по которым их можно отделить как от Императорских дворцовых загородных комплексах, так и от помещичьих усадеб. Такой особый тип объектов можно обозначить как «ближние усадьбы высшей знати». Это не Императорские пригородные резиденции, и не дворянские загородные дачи. Усадьбы (точнее - дворцово-парковые комплексы) высшей знати традиционно развивались как особый тип объектов на прилегающей к столичному городу территории. В настоящее время многие из них находятся в границах современной городской черты [8, с. 17].

По размерам (как зданий, так и парков) они существенно отличаются от рядовых дворянских усадеб. Здания для ближних усадеб высшей знати, как и для дворцовых загородных комплексов, строили известные придворные архитекторы, как бы сейчас сказали «модные», в модных в то время стилях.

К высшей знати, в контексте данного исследования, отнесены представители дворянства, приближенные ко двору, но не входящие в Императорскую семью, имеющие высокое социальное значение в структуре общества (не ниже 4 класса по табели о рангах).

В Санкт-Петербурге в разное время (века и десятилетия) существовали подобные усадьбы создавали вокруг города некий композиционный каркас в ряде литературных источников называемый поясом (зеленым кольцом). Постепенно, с увеличением границ города часть этих усадеб входила в состав города, они реконструировались, изменялись, исчезали. До нашего времени дошла только часть таких грандиозных усадеб, которые можно выделить в отдельный «слой» и рассматривать как отдельный феномен. 
Эти усадьбы создавали великолепные миры вокруг столичного города и были амбизиозными центрами притяжения, зачастую предрешая судьбу владельцев (Каменный остров - Бестужев-Рюмин). В некоторых случаях, когда владелец разорялся, такие усадьбы выкупались в казну города, становясь Императорскими резиденциями (Елагин остров, Таврический дворец и т.п.) иногда передавались лечебным организациям (Дача К.Е. Сиверса, Новознаменка и т.п.).

Одним из примеров таких «утраченных» усадьб является резиденция Державина на Фонтанке.

По берегам реки Фонтанки уже С 1710-х гг. раздавались земли для загородных дач царским вельможам, а 1724 г. Главная полицмейстерская канцелярия, которая велела отводом хмельных участков, определила их размеры (50 саж. в ширину и 100200 саж. в длину). Согласно указу Петра I от 11 февраля 1724г. каждый владелец должен был застроить свой участок в течение 4-х лет «по образцовым печатным о загородных дворах листам» и оставшуюся часть пилить огородом. Все это обусловило характер дальнейшей планировки района. На размер участков вдоль Фонтанки влияли две улицы Загородная и Садовая, проложенные вдоль ее берегов позади дворов. [4, с. 62]

В 1730-х тт. территория, на которой впоследствии располагалась усадьбе Державина, еще не была застроена. Небольшая загородная усадьба была устроена первым владельцем этой земли А.В. Олсуфьевым. [6, с. 254]

В январе 1788 г. дачу Олсуфьева приобрела жена сенатора и члена Российской Академии наук И.С. Захарова - М.П. Захарова.

В 1791 г. у Захаровой дом купили Державины. Официально владелицей усадьбы стала первая жена поэта Е.Я. Державина. Строителем дома являлся архитектор Конторы строений домов и садов ее величества Г.П. Пильников. После перехода дома к Державину, он остался при строениях и продолжал работы. [5, с. 94]

В 1741-1792 гг. к главному дому пристроили два равных по размерам прямоугольных флигеля. С домом они соединялись полуциркульными переходами в виде галерей и вначале были меньшими о протяженности, так что не доходили до набережной Фонтанки. [7, с. 399]

В 1813 г, не задолго до своей смерти Г.Р. Державин завещал дом на Фонтанке своей второй жене М Д. Дьяковой. После кончины поэта в 1816 г. значительных работ и усадьбе не проводилось. Часть участка, ближе к 1-й роте Измайловского полка, с 1825 г. арендовали под огород крестьяне Титов и Сорогин, с 1826 г. в наем был сдан деревянный дом.

В 1846 г. участок с домом Державина приобрела Римско-католическая духовная коллегия. Купчая была совершена 4 июня 1846 г. Дом для коллегии оказался не достаточно вместительным и началась его перестройка. [6, с. 254]

В доме расположилась коллегия, там же находились квартиры служащих коллегии, митрополии, каплица (часовня), канцелярия, архив и касса.

Одновременно с перестройкой дома для коллегии возобновились работы по саду. Проект был составлен в 1846г А.Гумлером. По нему он сохранял прежнюю планировку сада, при этом пруды соединил каналами, через которые были перекинуты мостики. В период с осени 1846 по весну 1847 г. в саду высадили деревья, устроили куртины и дорожки.

Часть участка в 1870г. была выделена под постройку здания для учреждений Могилевской епархии. 
К 1917 г. усадьба Державина сильно изменила свой первоначальный вид: утрачено большинство интерьеров, внесены существенные исправления в оформление фасадов. После революции здание было превращено в обычный жилой дом. [4, с. 64]

В октябре 1924 г. дом перешел из ведения правления жилтоварищества и распоряжение коммунального отдела. Здание выглядело крайне запушенным. В 1935 г. проходил неотложный ремонт кровли.

В 1936 г. помещения бывшего архива коллегии в западном крыле главного корпуса приспособили, под жилье. До этого времени их использовала мастерская технического комбината им. Фрунзе, вырабатывавшая гуталин.

21 августа 1919 г. Отдел по охране, учету и регистрации памятников искусства и старину принял здание под государственную охрану.

Сад - нач. 1930-х, частичная перепланировка, 1946 сад перепланирован, арх. А.Т. Тризна; 2-я пол. 20в.- частичные перепланировки.

В середине 1990-х гг. дом передан Всероссийскому музею А.С. Пушкина для устройства в нем филиала, посвященного жизни и творчеству Г.Р. Державина и русской словесности его времени.

Центральный корпус (музейный)- 2001-2003, реставрирован. Институт «Ленпроектреставрация», арх. А.Г. Белов, Л.А. Одинцова.

Таких усадеб, как Дворцово-паркового ансамбля Знаменской дачи, в разное время было не более 50, некоторые из них частично сохранились и дошли до наших дней, некоторые остались в истории и воспоминаниях современников тех лет. Наше время требуется сохранение этого исторически сложившегося феномена «ближних усадеб высшей знати» не только как градостроительных объектов, но и как фундаментальных следов развития культуры и дореволюционной жизни города. Столичный Санкт-Петербург не мог оставаться только в границах императорских резиденций, не мог существовать без этого великолепного ожерелья пригородных усадеб высшей знати.

\section{$* * *$}

1. Антонов, В. В. Святыни Санкт-Петербурга / В. В. Антонов, А. В. Кобак. - СПб. : Издательство Чернышева, 1996. - 490 с.

2. Богуславский, М. М. Международная охрана культурных ценностей / М. М. Богуславский. - М. : Международные отношения, 1979. - 192 с.

3. Канн, П. Я. Прогулки по Петербургу / П. Я. Канн. - СПб. : Палитра, 1994. - 320 c.

4. Колотов, М. Г. Дом Державиных и декоративные рельефы в его парадных интерьерах / М. Г. Колотов, Е. Ф. Ходаковский. // История Петербурга. - 2004. - 3 (19). - С. 60-69.

5. Пунин, А. Л. Архитектура Петербурга середины и второй пол. ХІХ века. Том 2. Петербург 18601890-х годов в контексте градостроительства пореформенной России / А. Л. Пунин. - СПб. : Крига, 2014. $-600 \mathrm{c}$.

6. Пыляев, М. И. Старый Петербург. Рассказы из былой жизни столицы / М. И. Пыляев. - М. : ДиректМедиа, 2007. -817 с.

7. Генрих, фонРеймерс. Санкт-Петербург в конце своего первого столетия / фонРеймерс. Генрих. СПб. : Росток, 2007. -534 с.

8. Семенцов, С. В. Развитие регулярной Санкт-Петербургской агломерации после Петра Великого и проблемы ее сохранения как Объекта Всемирного наследия / С. В. Семенцов. // Вестник гражданских инженеров. - 2014. - 4. - С. 16-24.

9. Федеральный закон от 25.06.2002 № 73-Ф3 «Об объектах культурного наследия (памятниках истории и культуры) народов Российской Федерации» // «Парламентская газета», №120-121, 29.06.2002 


\section{Матвеев М.Г., Сбеглов В.А. \\ Альтернативы пространственной организации городов}

Уральский государственный архитектурно-художественный университет (Россия, Екатеринбург)

doi: $10.18411 / s p c-28-10-2017-02$

idsp: 000001:spc-28-10-2017-02

История существования городов - это история преодоления проблем территориального формирования и развития с целью совершенствования условий жизни горожан.

До определённого момента города развивались стихийно. Как правило, потребности изменения планировочной структуры сопровождались решением проблем уже сложившихся городов, обусловливающих реорганизацию улиц в нерегулярной застройке, сооружение объектов общественного назначения -градостроительных акцентов, облегчающих ориентацию в застройке.

В 19 веке стихийно складывающиеся приемы формирования городов не предусматривали изменение плотности застройки с ростом населения. Следовательно, в процессе удовлетворения растущей плотности населения возникали потребности пространственной реорганизации структуры городов. Эти проблемы все более усугублялись во времени, порождая альтернативы пространственной организации городской структуры.

К наиболее ранним идеям, переосмысливающим развитие города, относится линейный город Артуро Сориа-и-Мата (рис.1). Он заявил, что построить новый город, соединяющий два крупных вдоль дороги между ними, проще, чем развивать существующий.

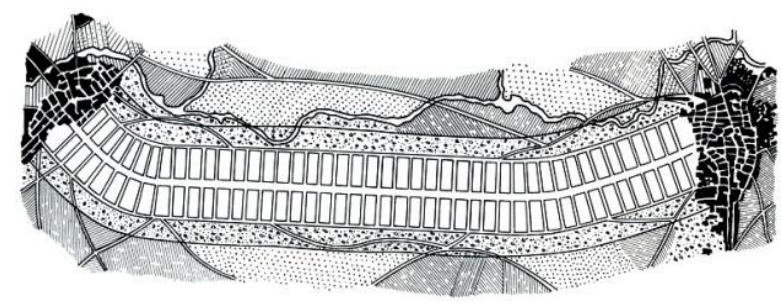

Рис. 1. «Линейный город» Сориа-и-Мата (1882 г.)

Определяющими принципами линейного города стали: а)развитие рельсового транспорта; б)создание сети линейных городов с мегаполисами в узлах; в)возвращение к природе.

В основе линейных городов-стремление побороть беспорядочную, стеснённую квартальную застройку, проблемы транспортной доступности, оторванность горожан от необходимой им живой природы. Современным этапом развития линейных городов является концепция нового элемента расселения (НЭР) (рис.2). Основой НЭР является крупная скоростная транспортная артерия с ячейками активной человеческой жизни«русло расселения», и привязанные к ней элементы расселения с более размеренной жизнью. Основной идеолог НЭР - профессор М Арх И, академик И.Лежава.

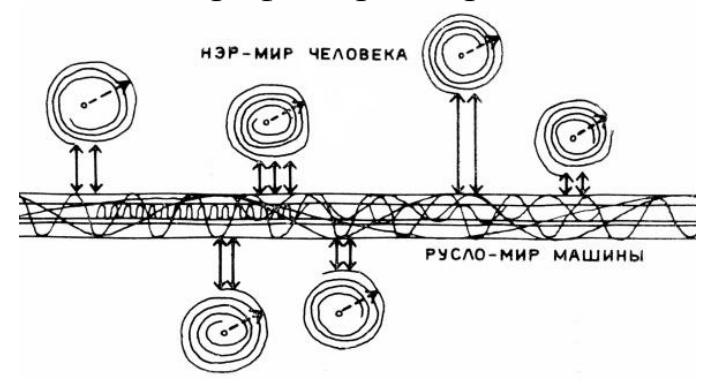

Рис. 2. НЭР. Схема ( 
Более смелой идеей трактовки города стала концепция надземного городаструктуры Ионы Фридмана(рис.3). Город представлял собой гигантскую надземную решётку, состоящую из опор и ярусов платформ. На платформах располагались транспортные магистрали и здания. Верхние уровни решётки предназначались для жилья и досуга, нижние - для предприятий обслуживания. При строительстве такого города не нужно гектарами вырубать леса, как это делают сегодня.

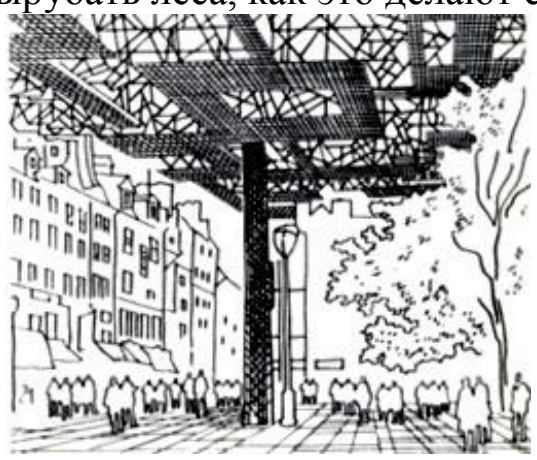

Рис. 3. Иона Фридман.Город-мегаструктура над Парижем

Таким образом, Фридман предложил развиваться не в плоскости ландшафта, а на искусственно созданных уровнях, расширяя возможности развития города и не убивая застройкой природу.

Объединение черт линейного и структурного городов прослеживается у японского метаболиста Кендзо Танге в его планах застройки Токийского залива (рис.4). По эстакаде, врезающейся в море, проходят магистрали с деловыми и общественными зданиями. Основным мотивом проекта является нехватка свободных площадей в переуплотнённом Токио.

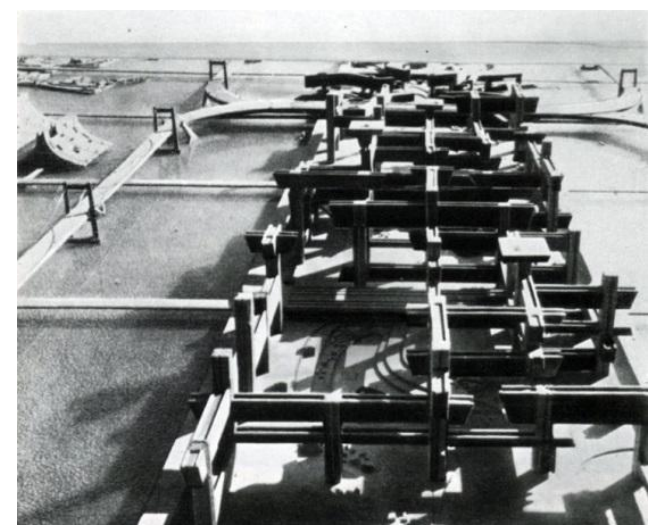

Рис. 4. Кендзо Танге. Проект Надводного Токио. Макет (1960)

Следующей, уже нестолько градостроительной, сколько философской концепцией города будущего стала «Аркология» Паоло Солери (рис.5).

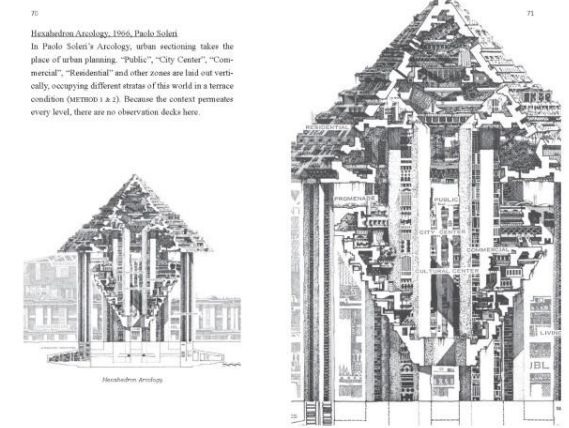

Рис. 5. Паоло Солери. Кубическая аркология (1960) 
Под аркологией понимают идею о том, что путём воздвижения гиперструктур, вмещающих целый город, можно снизить негативное воздействие поселений на окружающую среду. Предполагается, что заново отстраиваемые аркологии будут способствовать лучшему планированию и использованию общественного транспорта, что позволит повысить плотность населения, избегая при этом классических проблем больших городов.

Рассмотренные идеи пространственной организации поселений лежат в основе большинства существующих концепций. Выявим их общие черты:

- Жилые, общественные, производственные и иные городские объекты связаны скоростной сетью общественного транспорта, городских коммуникаций и энергосетей;

- Город переходит из состояния совокупности отдельных зданий к одной гиперструктуре, вмещающей все функции городского организма;

- Признаётся необходимость сохранения и ревитализации природного ландшафта. Здесь речь идёт не только об оздоровлении экологии места жизни человека, но о природе как самоценности.

$$
* * *
$$

1. Бунин А.В., Саваренская Т.Ф. «Градостроительство XX века в странах капиталистического мира. Том второй» - Москва: Стройиздат, 1979;

2. Линейная модель расселения: ретроспективный анализ концепции идеального города // Витюк Е.Ю.// «Архитектон: известия вузов»№47: http://archvuz.ru/2014_3/3;

3. Градостроительные концепции конца 19-начала 20в. // «Архитектура и дизайн»: https://archidizain.blogspot.ru/2012/02/19-20.html.

\section{Найденова И.В.}

Преемственность процессов модернизации аграрного сектора г. Корочи в рамках концепции развития агропромышленного комплекса Белгородской области

doi: $10.18411 / s p c-28-10-2017-03$

idsp: 000001:spc-28-10-2017-03

\section{Аннотация}

В статье рассматривается динамика развития предприятий аграрного сектора Белгородской области на примере малого города Короча с момента реализации постановления администрации от 14 декабря 1999 г., задавшего направление положительной динамики в сфере сельхоз производства. Несмотря на то, что развитие агропромышленного комплекса в малых городах региона происходит неравномерно, данный процесс на этапах реализации целевых программ характеризуется схожими чертами.

Ключевые слова: агропромышленный комплекс, агрохолдинг, сельхозпредприятие

Белгородскую область можно отнести к числу наиболее активно развивающихся регионов России [3]. По итогам 2015 г. был внесен весомый вклад в объем произведенной продукции сельского хозяйства (4,3\% и $17,7 \%$ продукции в России и Центральном Федеральном округе соответственно). Агропромышленный комплекс обеспечил около 30\% валового регионального продукта в 2015 г., что на 13\% превышает показатели 2009 г. Данные статистики подтверждают тенденции к развитию 
сельхозпроизводства в сравнении с горнодобывающей промышленностью, которая являлась главной опорой экономики области до 1999 г.

Корочанский район является территорией с исторически сформированным аграрно-индустриальным типом развития. По данным описей за 1900 г., в Корочанском уезде существовало более 50 промышленных предприятий, из них 27 предприятий пищевой промышленности, рассчитанных на оптовую торговлю, в том числе 6 медовопивоваренных заводов.

В период экономического кризиса, несмотря на финансовую поддержку администрации области, в результате физического и морального износа производственных мощностей к 1998 г. более 80\% сельхоз предприятий в регионе являлись убыточными, индекс рентабельности составлял $-21 \%$. Ситуация начала меняться в конце 1999 г. с принятием постановления «О мерах по экономическому оздоровлению неплатежеспособных сельскохозяйственных предприятий области». Основные положения принятой концепции оздоровления представлены на рис. 1.

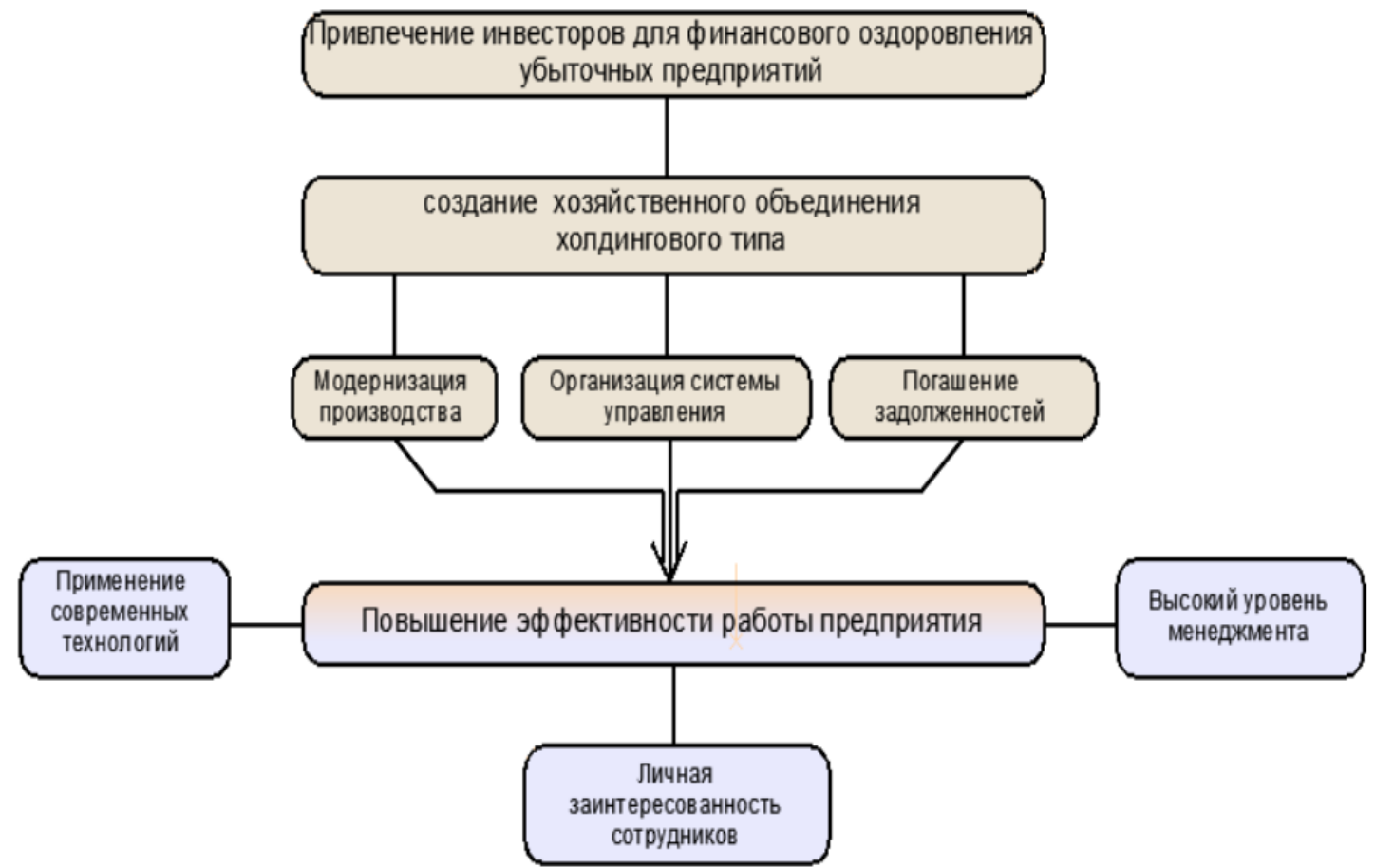

Рис. 1. Модель развития предприятий, не способньх самостоятельно вести производственную деятельность, сост. И. В. Найденова

Несмотря на то, что сроки реализации постановления были установлены до 2006 г., эффективность выбранного направления в аграрном секторе была подтверждена в течение двух лет. По итогам 2000 г. индекс производства продукции сельского хозяйства составил $120,3 \%$. Фактически, можно назвать данный результат отправной точкой положительной динамики развития агропромышленного комплекса в регионе, которая сохраняется и в настоящее время.

Преодоление последствий экономического кризиса, как в целом по области, так и в отдельных районах, стало возможно во многом благодаря переходу от текущего и среднесрочного планирования к разработке долгосрочных стратегий собственного развития [6]. Первым толчком к кардинальным изменениям в сфере сельхоз производства стало привлечение инвесторов и создание агропромышленных объединений холдингового типа. Заданный вектор движения был поддержан в 2006 г. в рамках приоритетного национального проекта «Развитие АПК» [7]. 
В Корочанском районе был сделан упор на развитие мясного кластера (активный рост отрасли начался в 2004 г. со стартом программ мясного животноводства) и перерабатывающей промышленности. В настоящий момент в указанных отраслях осуществляют деятельность такие агрохолдинги: «Мираторг», «Агро-Белогороье», «Зеленая долина», «Русагро». На рис. 2. представлены крупные сельхоз предприятия, действующие в концепции развития агропромышленного комплекса Корочанского района, начиная с момента реализации постановления администрации от 14 дек. 1999 г.

Как видно из рис. 2, одни крупные предприятия района были созданы в период внедрения современной стратегии развития аграрного сектора, другие преодолели последствия экономического кризиса, в настоящее время они реконструированы и модернизированы под современные промышленные объекты.

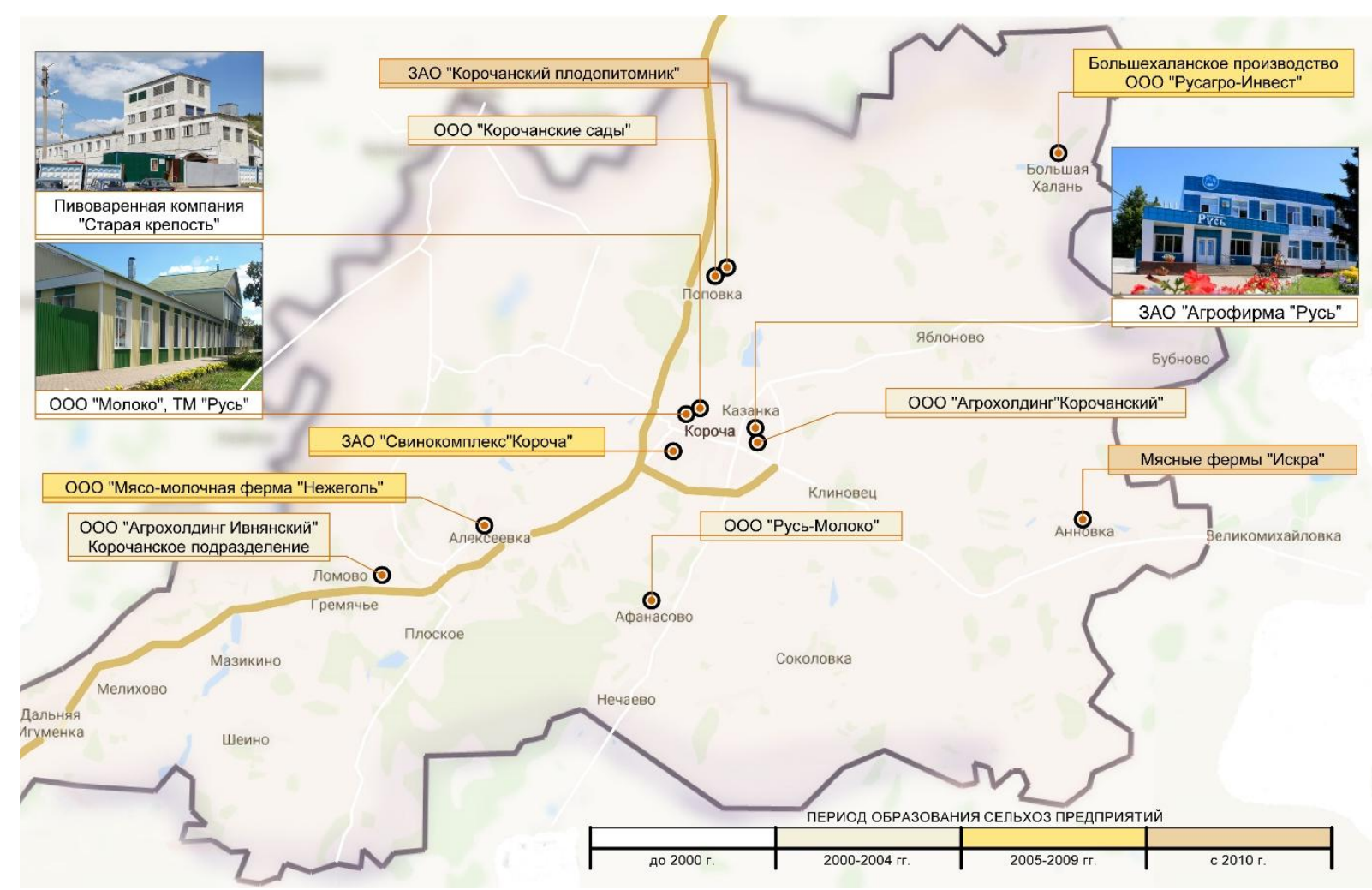

Рис. 2. Схема размещуения крупные сельхоз предприятия Корочанского района. Сост. И. В. Найденова

Так, на базе бывшего Корочанского райпищекомбната, основанного в формате артели еще в 1928 г., в настоящее время функционирует ООО "Пивоваренная компания "Старая крепость", в 2017 г. преобразованное из ООО "БЕЛОГОРЬЕ" и К". В качестве инвестора выступило руководство «Кондитерской фабрики «БЕЛОГОРЬЕ», восстановление происходило в рамках принятой программы «Реконструкции и модернизации производственного комплекса ООО "БЕЛОГОРЬЕ" и К"[9]. В период с 2015 по 2020 г. планируется в 5 раз увеличить производственные мощности предприятия.

В 1954 г. в Короче был введен в эксплуатацию маслозавод, рассчитанный на переработку 3000 т. молока в год, через 10 лет здание было модернизировано с целью увеличения производственных мощностей до 30000 т. в год. Сейчас предприятие продолжает выпуск молочной продукции под торговой маркой «Русь продукт».

Птицефабрика, образованная в с. Бехтеевка в 1965 г., после ряда преобразований, в 1998 г . постановлением главы Корочанского района, была 
реорганизована в ЗАО Агрофирма «Русь». В настоящий момент представляет собой современное многоотраслевое предприятие, с входящее в состав 300 лучших сельскохозяйственных предприятий России. Специализация: производство яиц и мяса птицы, яичного порошка, подсолнечного масла холодного отжима. В 2012 г. введен в эксплуатацию собственный завод по производству комбикормов.

Еще одним историческим промышленным объектом более чем с 50-летней историей является консервный завод в с. Поповка, который не был востребован в течение последних 10 лет. В 2000 гг. был взят курс на возвращение Корочанского района в число лидеров по выращиванию плодово-ягодных культур. С 2016 г. руководством ЗАО «Корочанский плодопитомник» реализуется проект по модернизации завода в связи с растущим спросом на местную продукцию в условиях следования тенденциям импортозамещения.

Местоположение Корочи как ядра, связывающего узловые населенные пункты области между собой, обусловливает перспективы его развития[10], в т. ч. на основе формирования градообразующих предприятий областного и федерального значения. В настоящий момент, агропромышленный комплекс в целом и его ведущая отрасль, сельское хозяйство, по-прежнему, испытывают ряд проблем, в числе которых:

- довольно высокая себестоимость производства в сочетании с невысокой доходностью от реализации некоторых типов продукции (например, производство молока);

- недостаточная конкурентособность небольших предприятий в сравнении с «агрохолдингами-гигантами» в условиях монополизации торговых сетей, что влечет за собой их ликвидацию, либо интеграцию в холдинговые струкуры;

- необходимость сохранения темпов устойчивого социальноэкономического развития территорий с целью предотвращения оттока населения и закрепления на местах молодых специалистов.

В связи с ухудшением экологического состояния природной среды[11], современный подход к решению вышеуказанных проблем должен базироваться на детальном анализе накопленного отечественного и зарубежного опыта в вопросах развития аграрного сектора, особое внимание следует уделить процессам экологизации и биологизации производства на основе применения передовых технологий в растениеводстве, животноводстве, пищевой промышленности[1] с целью сохранения природного потенциала сельхоз угодий и снижения негативного влияния производственной деятельности на окружающую среду.

$$
* * *
$$

1. Об утверждении государственной программы Белгородской области "Развитие сельского хозяйства и рыбоводства в Белгородской области на 2014-2020 годы" (с изменениями на 20.02.2017) [Электронный ресурс] : Постановление Правительства Белгородской области от 28 октября 2013 года №439-пп // 2005-2017. - Режим доступа: http://docs.cntd.ru/document/412303790. - 14.06.2017.

2. О мерах по экономическому оздоровлению неплатежеспособных сельскохозяйственных предприятий области [Электронный ресурс] : Постановление от 14 декабря 1999 года. - 1998-2018. - Режим доступа: http://docs.pravo.ru/document/view/13505874. - 14.06.2017.

3. Перькова М.В. Особенности планировочной структуры и перспективы развития городов с преобладанием горнодобывающей промышленности / М.В. Перькова, И.В. Найденова // Тенденции развития науки и образования: сб. науч. тр., по материалам XXI международной науч.- 
практической конференции 31 января 2017 г. - Ч. 4. - С. 31 - 35. - Самара: Изд-во НИЦ «ЛЖурнал», 2017 - 36 с.

4. Селюкова И. На пути к триллиону: Как белгородские аграрии планируют накормить страну / Ирина Селюкова // Белгородские известия. - 2016. - 24 сент. - С. 2.

5. Шедий, Е.Г. Агропромышленные холдинги Белгородской области. Практика формирования и эффективность функционирования наиболее крупных агрохолдингов (на примере Белгородской области) [Электронный ресурс] / Е. Г. Шедий // Российское предпринимательство. - 2011. - С. 177 180. - №1(2) (Экономика и экономические науки). - Научная электронная библиотека "КиберЛенинка". - 2011-2017. - Режим доступа: https:/cyberleninka.ru/article/n/agropromyshlennyeh... - 14.06.2017.

6. Ращенко А.В., Перькова М.В. Проблема развития общественных пространств в малых городах. Вестник БГТУ им. В.Г. Шухова. - 2015. - №1. - С.61-64.

7. Историческая справка [Электронный ресурс] : Официальный сайт органов местного самоуправления муниципального района "Корочанский район" Белгородской области. - 20092013.- Режим доступа: http://www.korocha.ru/istoricheskaya_spravka. - 13.06.2017.

8. Козлова Н. На корочанском консервном заводе будут выпускать тыквенный сок [Электронный ресурс] / Наталия Козлова // Белпресса. - 2016. - 10 июня. - Режим доступа: https://www.belpressa.ru/news/news/na-korochanskom-konservnom-zavode-budut-vypuskat-. tykvennyjsok13501/. - 13.06.2017.

9. История предприятия [Электронный ресурс] : офиц. сайт ООО «Пивоваренная компания «Старая крепость». - 2015. - Режим доступа: http://www.starayakrepost31.ru/o-nas/istoriya-predpriyatiya/. 16.06.2017.

10. Перькова М.В. Формирование линейно-узловой структуры расселения. Вестник БГТУ им. В.Г. Шухова. - 2017. - №2. - С.120-125.

11. Перькова М.В., Ладик Е.И. Формирование структуры туристско-рекреационных территорий Белгородской области с учетом региональных особенностей. Архитектура и строительство России. - 2017. - № 1 (221). - С. 85-92.

\section{Пешкова Д.А. \\ Выявление проблем типологического разнообразия городского жилья для людей пенсионного возраста}

(Россия, Самара)

doi: $10.18411 / s p c-28-10-2017-04$

idsp: 000001:spc-28-10-2017-04

\section{Аннотация}

В статье рассмотрены проблемы старения населения, демографическая ситуация в России нехватки жилья для престарелых. Рассмотрены варианты проблем решения расселения людей «третьего возраста»

Ключевые слова: пожилые люди, дома престарелых.

\section{Abstract}

The article considers the problems of population aging, the demographic situation in Russia, the shortage of housing for the elderly. The variants of the problems of solving the settlement of people of the "third age"

Key words: elderly people, nursing homes.

С 1960-х годов, в странах западной Европы, США и Австралии был повышенный интерес и устойчивый рост строительства зданий, для пожилых людей, в том числе жилья для престарелых, центров круглосуточного ухода и опеки за пенсионерами. 
На сегодняшний день проблема старения актуальна и стала ощутимо влиять на социальную сферу всей Восточной Европы, в том числе и России. В процессе демографического смещения среднего возраста и отток работоспособного населения в крупные города, обусловили сообщества низкой плотности с преобладающими по численности населением пенсионного возраста. Если управление регионов и предпринимает попытки материальной поддержки и медицинской помощи пожилым людям, то социальная сторона вопроса оказалась не разрешенной.

Несмотря на то, что программно-целевые инструменты действий в интересах пожилых людей в Российской Федерации стали использоваться со второй половины 90х гг., нельзя сказать, что они были основаны на комплексном подходе к этой проблеме. К сожалению, типология жилья для пожилых людей практически не исследовалась и не развивалась со времени распада СССР.

Увеличение доли пожилых людей в общей численности населения, считается одной из самых острых проблем человечества.Учёт тенденций и последствий демографического старения является важнейшей задачей демографической политики и должен быть увязан со стратегией формирования жилищной политики на государственном уровне.

Согласно статистики Росстата[1] в России с каждым годом количество пожилых людей увеличивается, но проблема расселения их никак не решается, когда в других странах, как Сингапур или Китай, активно занимаются возведением зданий для разных демографических групп населения.

В ходе исследования были изучены следующие примеры решений расселения пожилых людей:

Homefarm [2] находится в Сингапуре. Проект
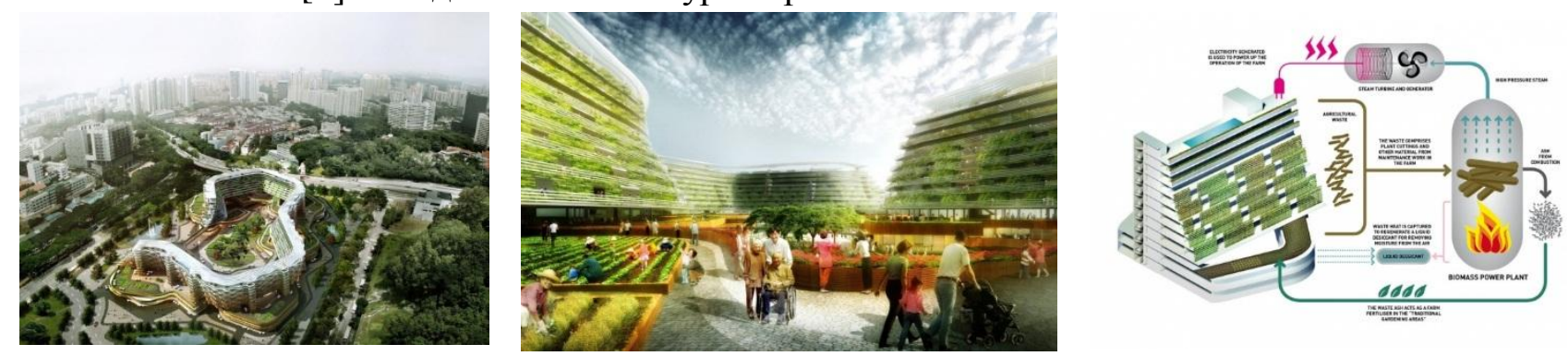

Архитекторы SPARK придумали проект Homefarm - жилой комплекс для пожилых людей со всей необходимой инфраструктурой, рынком, прудами и грядками для выращивания овощей-фруктов. Смелый концептуальный проект, по задумке авторов, поможет решить сразу несколько насущных проблем города-островагосударства Сингапур. Во-первых, он обеспечит растущий контингент пенсионеров доступнымжильем и создаст для них комфортную «среду обитания».Во-вторых, он предлагает решение экологической и продовольственной проблем посредством зеленых террас, крыш и вертикальных огородов, где будут расти свежие овощи и фрукты: их затем можно будет продать на рынке, запланированном на первом этаже, что обеспечит жителей доходом.

Жилой комплекс Homefarm позволит пенсионерам жить, словно на ферме, работать на грядках в свое удовольствие (столько часов в день, сколько им удобно), но при этом оставаться в городской среде, в окружении всей необходимой инфраструктуры, быть частью общества - и близкого по интересам сообщества.

Комплекс представляет собой криволинейный 8-этажный блок с жильем и длинными террасами-садами, который стоит на пяти 3-этажных подиумах, сгруппированных вокруг сада в середине и соединенных между собой переходами. На разных уровнях комплекса предусмотрены сельскохозяйственный центр, рынок, супермаркет натуральных продуктов, центры здоровья и социального обеспечения, 
библиотека, детский сад, торговый зал. За периметр комплекса вынесены четыре водосборных бассейна и въезд в подземный паркинг.

CheerfulCourt находится в Гонконге, Китай.
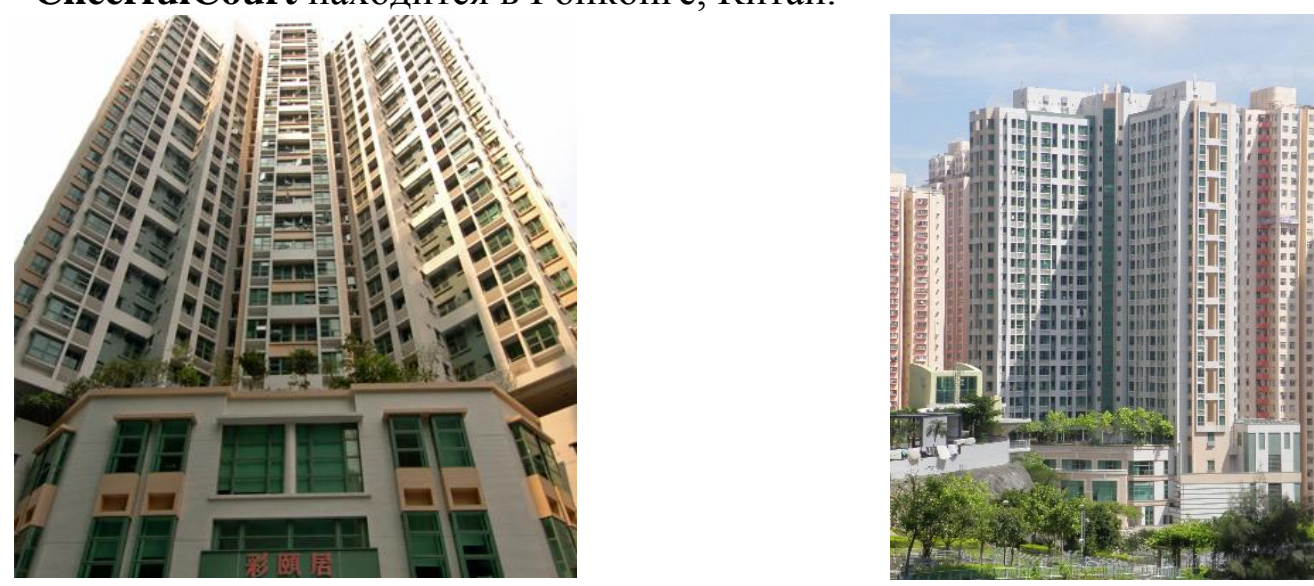

В Гонконге большое внимание уделяется стратегии развития и строительства государственного арендного жилья для пожилых людей. Основной принцип - создать условия для комфортной жизни стареющих людей в домашних условиях «ageinginplace». Основные задачи: интеграция жилья и услуг под одной крышей, поиск оптимального баланса между общественной и частной жизнью, обеспечение безопасности, соответствие разным уровням состояния здоровья. В данном доме 26 этыдей,333 квартиры по 23-35 кв.м.

Этот дом имеет самрфинансирование командой профессионалов из нескольких дисциплинарных групп, состоящих из зарегистрированных медсестер, социальных работников, физиотерапевтов и профессиональных терапевтов, объединенные в группы для оказания комплексных услуг по уходу за жильцами, позволяя пожилым людям жить достойно и мирно.

Архитектура социальных домов должна ориентироваться на потребности пожилых людей, для создания комфортных условий проживания необходимо понять процессы старения в физическом и социальном смысле, поведение пожилых людей и их восприятие окружающей среды в обществе.

Устойчивое развитие городской среды невозможно без комплексного решения таких проблем крупных городов, как нехватка доступного жилья для разных социальных и демографических категорий населения. Пути решения следует искать в направлении поиска новых, более рациональных градостроительных систем с высокой плотностью городской застройки, со смешанным использованием территорий и типологическим разнообразием жилья.

Как планировка пространства и концепция учитывают интересы граждан с проблемами зрения, слуха, равновесия и памяти? Выход на решение рассмотренных проблем требует также и пересмотра профессиональных преставлений о задачах, социальном смысле и самих объектах проектирования, которые сегодня остаются в плену у композиционно-эстетических соображений и часто далеки от реальности. В частности, необходимо развивать формы и методы диалогового проектирования, которое может опираться на средства массового автоматизированного проектирования. 


\section{JUURNAL_RU}

Научное издание

Научные тенденции:

Архитектура, География, Геология

Сборник научных трудов, по материалам

IV международной научно-практической конференции

28 октября 2017 г.

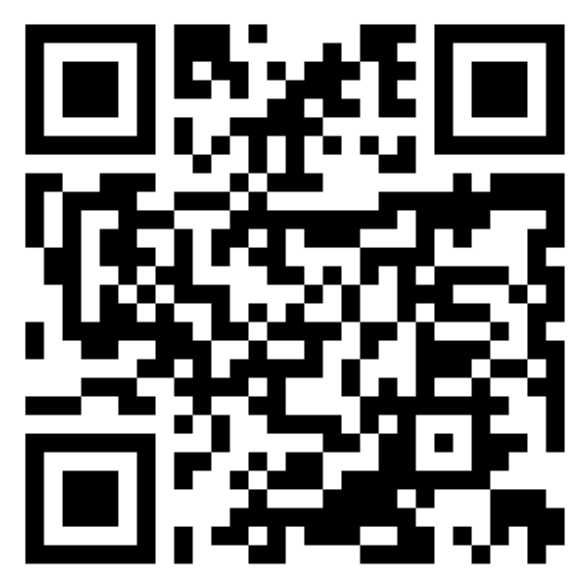

SPLN 001-000001-0197-AG

Подписано в печать 07.11.2017. Тираж 400 экз. Формат.60х841/16. Объем уч.-изд. л.0,92

Бумага офсетная. Печать оперативная.

Отпечатано в типографии НИЦ «Л-Журнал»

Главный редактор: Иванов Владислав Вячеславович 